ISSN 2076-3387

www.mdpi.com/journal/admsci

Article

\title{
Race to the Future: Innovations in Gifted and Enrichment Education in Asia, and Implications for the United States
}

\author{
Kathryn C. Ibata-Arens \\ Department of Political Science, DePaul University, 990 W. Fullerton Avenue, Suite 2200, Chicago, \\ IL 60614, USA; E-Mail: kibataar@depaul.edu; Tel.: +1-773-325-7336; Fax: +1-773-325-7337
}

Received: 26 September 2011; in revised form: 14 November 2011 / Accepted: 5 December 2011 / Published: 12 January 2012

\begin{abstract}
How are Asian countries preparing children to have skills-including creativity, innovation, and technical capability - to compete in the 21st Century global economy? Countries including China, Korea, Japan and Singapore have begun to integrate education policy and practice into a key component of national innovation strategies: human capital development. Asian countries are developing an emphasis on innovation and creativity at all levels of education, while the United States continues (via No Child Left Behind testing and budget cut-backs) to move away from that model. Developments in China (including Hong Kong and Taiwan), Korea and Singapore are complemented with comparisons to trends in national policy and private sector practice in Japan and the United States. Preliminary findings indicate that while progress has been made towards establishing education practices that enrich student learning, helping children to reach their highest potential in some countries, cultural practices and budgetary constraints have limited reform in others. The paper concludes with a summary of comparative best practices in enrichment education policy and practice and implications for globally competitive national innovation systems.
\end{abstract}

Keywords: gifted education; GATE; Asia; China; Hong Kong; Japan; Korea; Taiwan; United States; innovation; talent; education policy; science education; enrichment education 


\section{Introduction: The Rise of Asia}

In 2008 the journalist Fareed Zakaria published an article in Newsweek called "Rise of the Rest", which outlined the economic and cultural rise of Asia and other regions, and what this might mean to the future competitiveness of America [1]. On November 6 2011, Zakaria hosted a special on CNN entitled "Restoring the American Dream: Fixing Education" (CNN, 2011) [2]. In the program, the academic performance of $\mathrm{K}-12$ students in countries including Korea and Finland is compared to the lack of progress United States. Asian countries are also showing signs of catching up in what until now has been America's competitive advantage in innovation and entrepreneurship. OECD PISA (Programme for International Student Assessment) scores are one indicator of innovative capacity in human capital in this regard [3]. The following Table 1 outlines the increasing dominance of Asian countries in achievement across all measures: reading, math and science. Further, an interesting feature of the PISA scoring is that it places emphasis on students' abilities to demonstrate problem-solving skills and critical thinking (PISA has an ordinal ranking of a low 1 to a high 6 in this regard). Students who score at levels 5 and 6 demonstrate the highest mastery of complex tasks, according to the OECD [4]. Countries such as China and Singapore also lead in the percentage of top scorers across these measures [5]. The United States, while making some modest gains in math in the last five years, continues to decline overall. While not a direct indicator of the link between gifted education and student performance per se, the poor performance of American children compared to their Asian counterparts - even when normalized for socio-economic status - is an indication that something is amiss in education in the United States [6].

Table 1. PISA scores (Source: OECD, PISA 2009 database [4]).

\begin{tabular}{|c|c|c|c|c|c|c|c|c|}
\hline \multicolumn{3}{|c|}{$\begin{array}{c}\text { Ranking in } \\
\text { science performance }\end{array}$} & \multicolumn{3}{|c|}{$\begin{array}{l}\text { Ranking in } \\
\text { mathematics performance }\end{array}$} & \multicolumn{3}{|c|}{$\begin{array}{l}\text { Ranking in } \\
\text { reading performance }\end{array}$} \\
\hline Rank & Countries & $\begin{array}{l}\text { Mean } \\
\text { score }\end{array}$ & Rank & Countries & $\begin{array}{l}\text { Mean } \\
\text { score }\end{array}$ & Rank & Countries & $\begin{array}{l}\text { Mean } \\
\text { score }\end{array}$ \\
\hline 1 & Shanghai-China & 575 & 1 & Shanghai-China & 600 & 1 & Shanghai-China & 556 \\
\hline 2 & Finland & 554 & 2 & Singapore & 562 & 2 & Korea & 539 \\
\hline 3 & $\begin{array}{c}\text { Hong } \\
\text { Kong-China }\end{array}$ & 549 & 3 & $\begin{array}{c}\text { Hong } \\
\text { Kong-China }\end{array}$ & 555 & 3 & Finland & 536 \\
\hline 4 & Singapore & 542 & 4 & Korea & 546 & 4 & $\begin{array}{c}\text { Hong } \\
\text { Kong-China }\end{array}$ & 533 \\
\hline 5 & Japan & 539 & 5 & Chinese Taipei & 543 & 5 & Singapore & 526 \\
\hline 6 & Korea & 538 & 6 & Finland & 541 & 6 & Canada & 524 \\
\hline 7 & New Zealand & 532 & 7 & Liechtenstein & 536 & 7 & New Zealand & 521 \\
\hline 8 & Canada & 529 & 8 & Switzerland & 534 & 8 & Japan & 520 \\
\hline 9 & Estonia & 528 & 9 & Japan & 529 & 9 & Australia & 515 \\
\hline 10 & Australia & 527 & 10 & Canada & 527 & 10 & Netherlands & 508 \\
\hline 27 & United States & 502 & 44 & United States & 487 & 24 & United States & 500 \\
\hline
\end{tabular}

For several decades, American educators and policy makers have studied how the United States compares to Asian countries in terms of the institutions supporting human capital development. For 
example, in the early 1990s a report was commissioned in the United States: "National Excellence: a Case for Developing America's Talent (1993) [7]”. The report compared the education of gifted and talented students in China, Taiwan and Japan, and implications for education in the United States. It found that though gifted education programs in China and Taiwan were relatively recent, they were already ahead of developments in Japan at the time. The report concluded that the needs of U.S. gifted and talented students were not being met with then current practice, neither in terms of government policy mandates nor sufficient budget allocations. Nearly two decades later, the United States still lacks a comprehensive national policy on gifted education.

Meanwhile, the US is producing fewer and fewer college bound graduates who have the desire and skills to pursue careers at the technological frontier. As will be explained below, Japan lags behind other Asian countries in gifted education provision while the United States has faced a decline in its once stellar gifted education system. If we continue on this course, Japan and the United States shall end up as economic "has beens" in the rear view mirrors of countries speeding ahead towards a globally competitive future.

This paper begins with an overview of the significance of gifted education for national economies, outlining pioneering developments in gifted education in the United States as a point-of-departure. The next section provides an overview of recent innovations in gifted education policy and practice in Asia, highlighting developments in China (Beijing, Hong Kong, Taiwan), Korea and Singapore. The paper will conclude with lessons for Japan and the United States and suggestions for future policy.

The methodology of the paper is primarily a literature review of the scholarly literature in Chinese, English and Japanese regarding gifted education policy and practice, interviews with government and academic experts, primarily in China, Japan, Singapore and the United States, supplemented with interviews with young adults from these countries who have experienced gifted education and enrichment programs in these countries. Special emphasis is placed on developments in China and Japan, due to their population size compared to other East Asian countries.

\section{Overview of Gifted and Talented Education (GATE) and Its Importance in National Innovation Systems}

Gifted learners (130+ IQs) learn up to eight times as quickly as low IQ students and can, with the right kinds of teaching, master several years of grade level material in a single year [8,9]. Additionally, gifted learners need only a few exposures to new concepts to master them. Additional, redundant "drilling" has been found to lead to less retention, while experiential, hands-on enrichment activities enhance academic performance and student satisfaction across cultural contexts [10]. Gifted children, when provided with the right kinds of intellectual stimulation and enrichment, mature into leading scientists, entrepreneurs and innovators. This human capital development is an important part of a national innovation system (NIS). A national innovation system is comprised of a set of institutions and practices that underpin country-specific capacity in innovation (e.g., measured by patent output). For example, research institutions including top universities in the United States in the past have produced leading science and technology, as well as highly capable graduates to lead product developments in the public and private sector. A key component of a healthy national innovation system is nurturing all learners to reach their highest potential, and thereby maximize domestic human 
capital development. High ability learners, often referred to as "gifted" present a unique opportunity for maximum return-on-investment in this regard.

\section{Gifted Education in the United States: A Leader Falls Behind}

The field of gifted and talented education was pioneered in the United States in the late 1800s by the provision of special education to high ability students in individual schools, and later became a focus of national policy after the government response to the launch of the Soviet Sputnik Satellite in 1957 [11]. This "Sputnik Moment" in the United States led to a national level effort to improve the human capital development of the nation's high ability learners, particularly in the fields of mathematics, science and technology. The National Defense Education Act of 1958 was the first national level policy to support gifted education, and many millions of dollars poured into research and development of gifted education throughout the country. Other milestones include the enactment of the Jacob Javits Gifted and Talented Students Education Act (1988), which (until 2011) has provided five to ten million dollars annually for research and program development in GATE, focusing on low-income students. These early policies have since stagnated.

In the last decade NCLB (No Child Left Behind) driven testing has diverted resources towards "teaching to the test" and away from enrichment education [12]. In 2010, the National Science Board in the United States published a policy blueprint, "Preparing the Next Generation of STEM Innovators: Identifying and Developing our Nation's Human Capital [13]". The report resulted from a two-year study in collaboration with the National Science Foundation (NSF) and the Department of Education (DoE). The report faults NCLB for biasing getting children across the "basic proficiency threshold." The report concluded that the United States has "no 'standards of excellence' to which schools are held". The report also found that the U.S. education system is failing bright learners in low income, at-risk students-as most programs providing enrichment and STEM acceleration are not part of the formal curriculum of schools (e.g., are after-school, fee-based), nor are they mandated by any federal government policy. Further, the 2010-2011 biannual "state-of-the-states" report of the National Association of Gifted Children (NAGC) found a climate of national neglect vis a vis federal government support of gifted education, and as of September 2011, the future of the Jacob Javits Act - the only federal government funded program to support gifted education — was uncertain, having been eliminated from the House of Representatives 2012 budget [14]. In sum, the United States, despite having pioneered the provision of gifted education at local and national levels, has begun to prioritize standardized testing of its students, aiming to ensure that all schools are achieving academic "proficiency," rather than excellence.

Currently, a number of Asian countries are reforming their education systems away from rote learning and towards experimental/experiential formats. The following Table 2 provides an overview of key features in gifted education policy in select East Asian countries, including China (also Hong Kong and Taiwan), S. Korea, Singapore and Japan, as well as the United States. The appendix includes tables providing an overview of the number of students and educational institutions by grade level in these countries. 
Table 2. Key factors in gifted education (East Asian countries and the United States).

\begin{tabular}{|c|c|c|c|c|c|c|c|}
\hline Country & China (Beijing) & Hong Kong & Taiwan & Korea & Japan & Singapore & United States \\
\hline Establishment year & $1978[15]$ & $1990[16]$ & $1962[17]$ & 1997 & 2002 & 1984 & 1957 \\
\hline National policy catalyst & $\begin{array}{l}\text { The Establishment of } \\
\text { "Shaoer" Class }\end{array}$ & Pilot Program & $\begin{array}{c}\text { Primary } \\
\text { School } \\
\text { Administrator } \\
\text { Initiative }\end{array}$ & IMF Crisis & $\begin{array}{l}\text { MEXT allows } \\
\text { advanced } \\
\text { content in } \\
\text { textbooks }\end{array}$ & $\begin{array}{c}\text { Resource } \\
\text { Dependence } \\
\text { Requires } \\
\text { Human Capital } \\
\text { Investment } \\
95 \%+\end{array}$ & $\begin{array}{c}\text { Sputnik (1958 } \\
\text { National } \\
\text { Defense } \\
\text { Education } \\
\text { Act) }\end{array}$ \\
\hline Criteria & IQ $130+$ & Composite & IQ 130+1) & Composite & $\mathrm{n} / \mathrm{a}$ & $\begin{array}{c}95 \%+ \\
\text { percentile } \\
\text { achievement }\end{array}$ & Composite \\
\hline $\begin{array}{l}\text { Key institutional } \\
\text { leadership (early) }\end{array}$ & $\begin{array}{c}\text { University of Science and } \\
\text { Technology of China }\end{array}$ & $\begin{array}{l}\text { Government } \\
\text { Education } \\
\text { Commission }\end{array}$ & $\begin{array}{l}\text { The Fourth } \\
\text { Education } \\
\text { Conference }\end{array}$ & $\begin{array}{c}2000 \text { Law for } \\
\text { Promotion of } \\
\text { Gifted } \\
\text { Children }\end{array}$ & $\begin{array}{c}\text { MEXT, JST } \\
\text { Talent } \\
\text { Education Task } \\
\text { Force }\end{array}$ & $\begin{array}{l}\text { Ministry of } \\
\text { Education, } \\
\text { Gifted } \\
\text { Education } \\
\text { Branch }\end{array}$ & $\begin{array}{c}\text { Javits, } \\
\text { Elementary } \\
\text { and Secondary } \\
\text { Education Act } \\
{[18]}\end{array}$ \\
\hline $\begin{array}{l}\text { Key institutional } \\
\text { leadership (current) }\end{array}$ & Chinese Academy of Science & $\begin{array}{c}\text { Hong Kong } \\
\text { Academy for } \\
\text { Gifted Education }\end{array}$ & $\begin{array}{c}\text { Chinese } \\
\text { Association of } \\
\text { Gifted } \\
\text { Education }\end{array}$ & $\begin{array}{l}\text { National } \\
\text { Research } \\
\text { Center for } \\
\text { Gifted and } \\
\text { Talented } \\
\text { Education }\end{array}$ & $\begin{array}{c}\text { MEXT, JST } \\
\text { Talent } \\
\text { Education Task } \\
\text { Force }\end{array}$ & $\begin{array}{l}\text { Ministry of } \\
\text { Education, } \\
\text { Gifted } \\
\text { Education } \\
\text { Branch }\end{array}$ & $\begin{array}{c}\text { Varies by } \\
\text { State and } \\
\text { School } \\
\text { District [19] }\end{array}$ \\
\hline
\end{tabular}


Table 2. Cont.

\begin{tabular}{|c|c|c|c|c|c|c|c|}
\hline Country & China (Beijing) & Hong Kong & Taiwan & Korea & Japan & Singapore & United States \\
\hline Establishment year & 1978 & 1990 & 1962 & 1997 & 2002 & 1984 & 1957 \\
\hline \multicolumn{8}{|l|}{ Provision } \\
\hline Clustering (by class) & Y & Y & Y & Y & $\mathrm{N}$ & $\mathrm{Y}$ & Y \\
\hline In-class differentiation & Y & Y & $\mathrm{Y}$ & Y & $\mathrm{N}$ & $\mathrm{Y}(3)$ & $\mathrm{Y}$ \\
\hline $\begin{array}{l}\text { Sorting to gifted schools by } \\
\text { entrance/screening exam }\end{array}$ & Y & Y & $\begin{array}{l}\text { "Banding" to } 3 \\
\text { H.S. levels }\end{array}$ & Y & $\begin{array}{c}\text { "Super } \\
\text { Science" H.S. }\end{array}$ & Y & Y \\
\hline $\begin{array}{l}\text { Enrichment in school } \\
\text { (pull-out) }\end{array}$ & Y & Y & Y & Y & $\mathrm{N}$ & Y & Y \\
\hline Enrichment after school & $\mathrm{Y}$ & $\mathrm{Y}$ & Y & $\mathrm{Y}$ & Cram Schools & $\mathrm{Y}$ & Y \\
\hline Grade levels & $6-12$ & $\mathrm{~K}-12$ & $\mathrm{~K}-12$ & $4-12$ & $\mathrm{n} / \mathrm{a}$ & $4-12$ & $\mathrm{~K}-12$ \\
\hline
\end{tabular}

(1) Composite $=$ Selection by measures of aptitude (IQ) and achievement scores (math, verbal, visual spatial) skills.

(2) As of 2011 Japan had no formal policy supporting gifted education.

(3) Emphasis on experiential learning and independent studies. 
Countries are compared in terms of the events precipitating the introduction of gifted education, leading institutions in the early reform period and today, and the types of gifted/enrichment services students receive. The role of government, as well as private sector actors is highlighted. The Appendix includes tables summarizing the population of students across countries as well as number of schools by grade level.

"Gifted" education includes curricula tailored to the individual needs of high aptitude student and often focuses on critical thinking and related analytical skills. "Enrichment" education is similar, and is provided to students who have already mastered current grade levels of content in primarily math and reading. In enrichment, high achieving students (regardless of a "gifted" identification) receive higher than grade level content instruction in content areas. Enrichment is often worked in addition to regular classroom work and for this reason supplemental after school programs are often confused with gifted enrichment. The following sections review the history and current trends in gifted education policy and practice in China, Hong Kong, Taiwan, Korea, Singapore and Japan. Particular attention is paid to historical catalysts that led to education policy reform, and in the case of Japan, the barriers to reform.

\section{Gifted Education in China: Educating the "Super Normal"}

\subsection{History}

One of the many impacts of the Cultural Revolution in China was a lost generation of students, particularly high ability students who could not pursue their academic goals. On a societal level, this led to introspection about how to invest in future generations of human capital to fuel China's growth. In 1978, the University of Science and Technology of China created a program for accelerated education for gifted students [20]. According to Chan, the writings of Confucius categorize the intellect/abilities of people into superior (上)、 mediocre (中) and inferior (下). Further, though naturally talented people, tian cai (天才) were thought to be blessed by heaven, Confucius emphasized the role of education and effort in becoming smart [21]. At the same time, Confucian beliefs of obedience and harmony, in retrospect, hindered the development of creativity in education practices [22].

In China, the percentage of the gifted children is estimated to be between $1 \%$ and $3 \%$ of the total population of children. For example, in Beijing (2010), the number of the children under 14 years old is 1.878 million of which 18,800 would be considered as gifted (there are 6 school districts in Beijing, comprised of 2,671 (1361 kindergartens and 1310 primary) schools (2007). On a national level there are 289.76 million children under 14 years old, and therefore, about 8-10 million gifted children 14 years or younger in China (Though the population size is of Japan is much smaller than China, it is worth noting that in contrast, in Japan, there are a total of 12.5 million students in the entire $\mathrm{K}-12$ pipeline) [23]. There are more than 55 thousand $\mathrm{K}-12$ schools in China, distributed across 23 provinces, 4 municipalities (Beijing, Shanghai, Tianjin, and Chongqing), 5 autonomous regions and 2 special Administrative regions (Hong Kong and Marco). There are 65 "top" middle schools and 44 
top high schools in Beijing, 92 top universities in China [24]. Many of these universities are in urban cities such as Beijing, Guangzhou, Nanjing and Shanghai.

By 1985, Middle School Number Eight in Beijing collaborated with the Chinese Academy of Science created the “middle school gifted education class", also named “Shaoer" (少年) class [25]. Since the program began in 1978, more than 70 primary or middle schools in China have created gifted children's classes. The Shaoer program has continued for more than three decades and there are more than 900 Shaoer graduates. Eighty percent of Shaoer graduates have continued on to graduate schools. The percentage of enrollment in the top 10 graduate schools in China averages approximately $10 \%$ of applicants [26], while the percentage of Shaoer students admitted into China's graduate schools is over $70 \%$.

\subsection{Mode of Provision}

In China, there are three modes of provision of gifted education: advancement, enrichment, and pull-out (such as the Shaoer program described above). Advancement includes early admission and grade skipping. In China, children begin primary school at the age of 6 to 7 years old. Gifted children may gain admittance earlier. Gifted children are also allowed to skip grades, depending on the level of their performance. Enrichment and pull-out are also provided.

\subsection{Gifted Schools}

The first gifted (primary to high school) school was established by the University of Science and Technology (UST), Beijing. Students are selected by an entrance exam in primary school. Upon graduation from UST, students enter university without having to take an entrance exam [27]. Other ways that China supports the education of gifted students include High School level "Olympiad" competitions in math and physics. Students, via a screening exam are eligible to take special courses to prepare for the Olympiad competitions. Winners of these competitions are granted admission to the top universities without having to take an entrance exam. In China, there is a standard entrance exam for all universities, unlike Japan, in which each university has its own exam (which is a boon to the supplemental education industry in Japan, as test prep must be tailored to each exam).

The most famous Gifted Education Institution in China is the "Supernormal Class" which is administered by the GUCAS (Graduate School of the Chinese Academy of Sciences), Beijing and Beijing YuCai School. The students are enrolled at the age of 6 and attend primary, middle and high school through the program. In China, the Supernormal Class of GUCAS is known for its students' performance, most of them become well-known scientists, entrepreneurs, scholars and the like [28]. Hong Kong, partly due to its small size compared to mainland China, has been able to develop a wide variety of gifted interventions. 


\section{Hong Kong: Multi-faceted Provision of Gifted Education}

\subsection{History}

The national government's attention to gifted education began in 1990, when a group of educators from the Ministry of Education proposed to establish a commission to investigate the potential for gifted education in Hong Kong. In this year, the Education Commission (The Commission was comprised of representatives from Ministry of Education) Report No.4 initiated the development and implementation of gifted education in Hong Kong (HK) by recommending the development of school-based programs to cater to the needs of gifted students. The report also explored the definition of gifted children and their learning needs [29]. In the academic year 2008-2009, there were over a million children in the 2,336 K-12 schools in Hong Kong. Of this number, about 50,000 were gifted.

Referring to the Education Bureau (EDB) of Hong Kong's multi-faceted definition of gifted, the 1990 report concluded that giftedness should be determined by a composite measure of natural abilities and competencies [30]. In 1994, The "Pilot School-based Programme for Academically Gifted Children" was launched by the Education Department (which became the Education and Manpower Bureau in 2003). Hong Kong has one of the most developed gifted education policies of the countries studied, and it provides highly attenuated levels of provision of gifted services, while attempting to expose all students - not limited to those identified as gifted - to some level of gifted education. Government subsidized gifted schools are supplemented by private and international schools offering supports for gifted learners. The figure below illustrates the three main levels of provision, and how each is further separated into general enrichment and specialized curricula [31].

Figure 1. Levels of gifted services in Hong Kong.

\section{OPERATION}

Level3: off-site support

Level2: pull-out (school-based)

Level1: whole class (school-based)

\begin{tabular}{|l|l|}
\hline $\mathrm{E}$ & $\mathrm{D}$ \\
\hline $\mathrm{C}$ & $\mathrm{B}$ \\
\hline $\mathrm{A}$ & $\begin{array}{l}\text { Specialized (Subject } \\
\text { /Domain focused) }\end{array}$ \\
\hline $\begin{array}{l}\text { Generic (General } \\
\text { enrichment) }\end{array}$ & NATURE \\
\hline
\end{tabular}

\section{Level 1}

A: All students in all classrooms are exposed to high order thinking skills, creativity and personal-social competence, all of which are core tenets of gifted education.

B: Differentiated teaching tailored to the needs of the groups with enrichment and extension of curriculum across all subjects in regular classrooms.

Level 2

C: Pullout programs for gifted students, where the emphasis is on teaching to a homogeneous group of high achieving students, while augmenting general curricula in the regular classroom. 
D: Pullout programs in specific subjects, including math and art, which allows systematic training of students demonstrating high performance in these areas.

\section{Level 3}

E: Individualized educational arrangement for the exceptionally gifted who requires resource support outside the regular school (e.g. Counseling, mentorship, early entry to upper level schools, etc.)

\subsection{Leading Institutions}

The early development of Gifted Education in Hong Kong (HK) was led by the Ministry of Education, in collaboration with specific education institutions, including Fung Hon Chu Gifted Education Centre. In August 2008, the Hong Kong Academy for Gifted Education was established jointly by Sir Joseph Ho Tung and the Ministry of Education, which funded 1 million Hong Kong dollars each. Since 2008, the Hong Kong Academy for Gifted Education has led the selection and education of gifted children in HK [10]. In terms of provision, the Academy focuses on Level 3 learners (the highest ability group), representing the top two percent of the population of learners [32].

From 1997 to 1998, the Education Department conducted the evaluation on "Pilot School-based Programme for Academically Gifted Children" to examine the process and outcomes of the pilot scheme. As a result, further improvements to gifted education were made [30]. Under this programme, educational psychologists provided regular school-based support to the pilot schools on programme planning, curriculum development, student selection and teacher training. Like Hong Kong, Taiwan began with a local-school level pilot that was scaled out to the national level.

\section{Taiwan: Teacher Initiative}

\subsection{History}

Interest in gifted education in Taiwan began after a group of primary school administrators proposed new approaches to enriching the education of their brightest students; in 1962, the "Fourth Conference on Education" in Taiwan proposed creating gifted education on the principle that gifted children should be educated appropriately to their level of aptitude. At this time, a screening method was established, and initial identification for subsequent testing was done in collaboration with classroom teachers and parents. Eligible students take an intelligence test where an IQ of 130 or higher is the benchmark for giftedness. Former Education Minister Kuo Wei-fan estimated that based on these criteria, the ratio of gifted children is between three to five percent. These students might be allowed to skip up to two years ahead of their age cohort. In 2010 in Taiwan there were more than seven thousand $\mathrm{K}-12$ schools educating three million students, including a gifted population of up to 150,000 students.

The notion of giftedness has broadened over time in Taiwan. For example, Articles No.4,28,29 of the Special Education Law (Education Administration, 2008) show that the definition of giftedness has been enlarged to include students with excellent potential and outstanding performance in six 
domains: general intelligence, academic character, art, creative ability, leadership skills and other specialties. There are also laws for high-achieving students who are able to enter school at a younger age and skip grades.

\subsection{Provision}

In Taiwan, there are three main methods of gifted education provision, namely, enrichment, acceleration and grouping. Enrichment includes extended curricula, in-depth teaching materials, and a greater variety of learning activities than those for regular students. Acceleration includes early admission to upper level schools, compacted curricula timelines, grade skipping, as well as exemption from certain (e.g., university entrance) examinations. Grouping includes special ability-based classes and resource room based teaching ("resource room" here means the talented students are grouped into special classrooms having more diversified and varied materials and/or equipment) [33].

In accordance with The Act of Special Education promulgated in 1984, gifted and talented students are divided into three types of classes for instruction:

\subsubsection{Gifted and Talented Student Classes}

In the early years, gifted and talented students were educated in centralized special classes. In 1979, decentralized classes for gifted and talented students were introduced. For example, in 1979 Taipei's Primary and Secondary school created centralized classes to educate gifted and talented students of the general abilities category. These decentralized classes replaced centralized classes. Gifted and Talented students were dispersed across four or five classes. In cases where students were grouped according to their scholastic abilities of different subjects (Mandarin, English, mathematics, and physics), they were taught depending on their abilities of the subject. The classes for these courses had to be arranged so that those gifted and talented students could attend the same classes at the same time. A number of assessments confirmed that gifted students who benefited from separate classes and resource rooms showed better creative thinking and academic achievement across subjects, including math and science, than control groups of high ability learners in regular classrooms [10]. Currently, most general abilities and scholastic aptitude classes are resource classes.

\subsubsection{Artistic Talent Classes}

Artistic talents fall into three categories - music, art, and dance. Experimental music classes were the first to be established. For example, from as early as 1963, Taipei's private Guangren Primary School had an experimental music class. In addition, art classes were all centralized classes for gifted and talented students. Students were clustered, with an emphasis on cultivating outstanding artistic talent or performing individuals.

\subsubsection{Other Special Talent Classes}

Classes for students with special athletic abilities are most common.

Education in Taiwan, including gifted and talent education, has evolved from earlier segregated special schools for the physically and mentally challenged, to centralized special education classes, 
decentralized resource classes and home education [34]. Though slower to develop than Taiwan and other Asian countries, since the IMF Crisis in 1997, Korea has pursued a fast-track of gifted education development.

\section{Korea and the IMF Crisis as Catalyst}

\subsection{History}

There are nine provinces and six municipalities in Korea. 19,313 K-12 schools educate 8.3 million students. As of 2008, about 50,000, or 0.72 percent of elementary and middle school students participated in education for the gifted (out of an estimated 415,000 high ability students) [35], Gifted education in Korea was slower to develop than other East Asian countries (save Japan). For example, the first introduction of specialized education, sponsored by the Ministry of Education, began in 1983 when a science high school was established in Seoul.

In 1995, the government introduced acceleration systems including early entrance into elementary school, grades skipping and early graduation. In 1997, special admission to universities for prize winners from international (science and math Olympiads) competitions was established. In the 1980s and 1990s in Korea, however, the focus was mostly on grade acceleration rather than same grade enrichment.

The 1997 Korean IMF Crisis (precipitated by the Asian Financial Crisis) led to rapid developments in gifted education, as national leaders recognized weaknesses in developing national human capital. By 2000 a new Gifted Education Law was enacted and became effective since March 2002. According to the Law, gifted education is implemented in three ways: gifted high schools, gifted education centers (for primary and middle school students) as a pull-out program operated by universities and school boards, and gifted classes as a pull-out program in regular schools.

Since the first science high school was created in 1983, each year new schools have been added. Currently there are 16 science high schools. In addition, the Busan Science Academy was established as an official gifted school in 2001. With the financial support by the Ministry of Science and Technology, fifteen gifted education centers affiliated with universities have been established and are currently providing enrichment programs of mathematics and science. Sixteen of the twenty-three school districts provided pull-out programs for their gifted students. Furthermore, as of 2008 more than 3,000 students attended enrichment classes (weekends, summer) at university affiliated gifted education programs. About 7,000 students, ranging grade 4-9, are enrolled in gifted classes [36].

\subsection{Selection}

Gifted education is mainly implemented following three processes: student selection, education, and evaluation for reselection. In Korea there are a number of ways to identify gifted students. Two common criteria across approaches in Korea are that they share a 'multiple-step evaluation processes' and 'evaluation based on mathematical creativity or advanced mathematical thinking capability [36]'. 
Entrance to science high schools is determined by performance in math and science (measured by placement tests and/or science Olympiad performance), as well as an oral examination.

\subsection{Provision}

As mentioned above, the Busan Science High School (BSA), established in 2001, was the first official gifted school. The selection process of new entrants to BSA consists of three phases. Applicants are screened on the basis of math and science test scores or top performance at national or international science and math competitions. In the second phase, creative problem solving abilities in mathematics and sciences are evaluated. The third phase of the selection process is a four-day long camp. Students demonstrate their abilities in problem identification, experimental design, data collection, drawing conclusions, and presenting and communicating results in front of audience.

In 2009, Seoul Science High School began the process of conversion into a school for the gifted. Further, the Primary and Middle School Education Act (2009) and the Gifted Education Act (2009) promoted the creation of specialized high schools and additional schools for the gifted. In 2005, a program was undertaken to identify and educate the gifted children of socioeconomically underprivileged people. Since then, more than 1,800 students have joined the program. Unlike applicants for education centers or classes for the gifted, these candidates were selected through critical thinking tests (not subject-oriented tests, often thought to have a bias towards students of a higher socio-economic status) [35]. Singapore is similar to Korea in its nurturance of high ability students - regardless of socioeconomic status, and in addition, country-of-origin.

\section{Singapore's Human Capital Investment}

In the 1960s, Singapore was still an undeveloped backwater, lacking basic infrastructure. Locals report that the river that runs through the downtown area was so polluted that it stank in the humid summer air. It was not safe to swim in it. At the time, Singapore's labor force was generally unskilled and the economy had no international market presence.

Today, Singapore is a mecca for talent, boasting several high technology/biotechnology R\&D and manufacturing centers, housing global firms including 3M, Baxter, Medtronic and Siemens. Singapore's streets are clean and safe, its high skilled labor force is paid well and a re-distributed tax system ensures that the local population has access to quality housing and public education. The path to Singapore's current high technology hub status was several decades in the making, forged by key leadership initiatives.

\subsection{History}

In 1981, the late Dr Tay Eng Soon, the Minister of State for Education, led a mission to study the gifted education programs in other countries. This mission's findings confirmed a compelling need to start a gifted education program - given that Singapore was a small country, with little more than its human resources as a basis for its future prosperity [37]. 
In 1984, a pilot project was started by the Ministry of Education (MOE) in 2 primary schools, Raffles Girls' Primary School and Rosyth School, and 2 secondary schools, Raffles Girls' School (Secondary) and Raffles Institution. This pilot became the basis for national policy, the "Gifted Education Programme (GEP) [38,39]".

Students scoring in top ten percent on achievement exams in Singapore are eligible for additional testing to determine eligibility for gifted services. Thus Singapore has the broadest definition of the gifted among the countries studied. Further, the Gifted Education (GE) branch of the MOE determines if a child is "exceptionally" gifted by looking at 4 sets of information: a psychological report, achievement and aptitude/above-level test scores, samples of the child's work, and teachers' recommendations. The Ministry of Education (MOE) formally identifies the academically gifted and caters to the top $1 \%$ of the national cohort through the Gifted Education Programme (GEP), beginning at Primary 4. It also caters for the exceptionally gifted. About 500 pupils (out of 4000 pupils tested) are admitted into the Program at primary grade level 4 each year [40].

\subsection{Provision}

Interventions for gifted children are extensive. These include enrichment (student learns topics which are taught in greater depth and breadth), self-paced instruction, online courses (above grade level), mentorship (student is matched with a mentor who provides advanced training and experiences in a specific content area), subject acceleration (student is placed at a higher grade level in the specific subject while remaining with his/her age cohort for other subjects), dual enrollment (in more than one school), early primary school admission (at age 5), and grade skipping (up to 4 grades) [41].

According to the Ministry of Education in Singapore, the number of pre-university children in Singapore is 521,594 (2009) [42]. In a normally distributed population, there are about three such exceptionally gifted among 100,000 children [43]. So it is estimated that the number of exceptionally gifted children in Singapore is 16 in 2009. Despite its small population, Singapore has found a unique way to increase its numbers of gifted and talented youth, and other countries have taken notice.

Singapore has become a city-state to emulate, as communities all over Asia (including Okinawa, Japan) try to copy its success. Decades of smart national policy_prioritizing infrastructure and human capital investment while attracting foreign direct investment-are the basis of Singapore's success. Its national innovation system architects, including Philip Yeo, have focused on investment in education [41]. The national government has expanded its gifted education policy to attract the best and brightest from other countries to settle in Singapore. One example is the "guppies to whales" program sponsored by The Singapore Agency for Science, Technology and Research (A Star) $[44,45]$. Rising star primary, middle and high school students with talent in math and science are identified in Singapore and other, particularly Asian countries. They are then eligible for Singapore national government sponsored scholarships and fellowships all the way through to doctoral study. To enhance the long term brain gain for Singapore, foreign students are required to accept Singaporean citizenship and are also required contractually to work in Singapore for at least 
3 years upon graduation [46,47]. Local students are also eligible for similar sponsorship programs [48]. Japan's situation is quite different.

\section{Japan Lags Behind}

An April 2010 article in the Mainichi newspaper noting the innovations in life science based experiential learning at the Yokohama City Science Frontier High School (one of the "Super Science" designated schools, discussed below) [49], at the same time lamented the lack of development of a national gifted education system [50].

Gifted education remains an anathema in Japan, as it is strongly associated with elitism. This is partly due to the strong cultural undercurrent that hard work and effort leads to academic success, not innate ability [51]. Further, the terms eisai 英才(えいさい) and shusai 秀才（しゅうさい) referring to the "gifted" and are strongly associated with notions of elitism, as in pre-modern Japan, only the children of the samurai class and higher had access to education.

A 1994 article examining Japan's and other Asian countries attempts at gifted education concluded that gifted education will "not be part of the government-sponsored educational system" (Stevenson et al. [52]) The term "gifted" remains taboo today, and MEXT instead advocates the use of the term saino kyoiku 才能教育（さいのう）“talent education” to refer to gifted education.

\subsection{History}

There is virtually no formal structure in Japan to support the education of gifted students. There are no "gifted" schools in Japan. The majority of schools rely on MEXT (Ministry of Education, Culture, Sports, Science and Technology) curriculum guidelines (for public schools this is mandatory). Consequently, classroom teachers have had little latitude in providing differentiation and/or acceleration for academically talented students (and thus might be a partial explanation of the size of the market for supplemental education in Japan). However, there are a few examples of individualized, adapted education practices, including those designated by MEXT as Super Science High Schools, including the Kyoto Municipal Horikawa Senior High School [53]. As part of the 2002 MEXT reforms, an attempt was made to balance rote learning with more individualized education yutori kyoiku (ゆとり教育), but with the existing emphasis on entrance exam preparation for middle school and the higher grades, this has proven difficult [54].

Also in 2002, the Japan Science and Technology Agency, part of MEXT, initiated the Super Science High School (SSH) program in response to declining student scores and interest in math and science. Under SSH, designated high schools are provided with additional funds to support science and math education and also to foster links with universities, including faculty-student mentoring programs. In 2010 there were 126 Super Science High schools in Japan [55]. In 2006 there were 12.6 million K-12 children in 48,107 schools. Estimating at five percent of this population, more than half a million students could be gifted. Since Japan lacks a formal identification system, the Japanese government does not track statistics on the number of gifted students at this time. 
A government task force was established by MEXT in 2007 to explore possibilities for reforming the national education system in support of science education. In 2010 a report was published indicating the need for the creation of a national system of talent education. One finding was that students attending a SSH were far more likely to participate in International Science Olympiads [56]. Since the field of gifted and talented education is so new in Japan, the bulk of Japanese scholarly research on gifted education has heretofore focused on studies of other countries, often China and Korea [57-60].

Due to the "relations" that many private schools have in placing graduates in elite universities, the competition to attend private primary schools is high. Entrance is said to be based on aptitude of the students, but entrance exams also include interviews with parents. At the middle school level, private schools have curriculum designed to prepare students for entry to high school and subsequently elite universities, and a more tailored, especially science-based curriculum is available to students. For those aiming to attend university, the “test” (o-juken, お受験, おじゅけん) system begins as early as pre-school. A multi-billion dollar a year test-prep industry is fueled by the intense competition within the school entrance exam system in Japan. Companies such as Kumon and Benesse have built multinational corporations in this space as a result $[61,62]$.

At the high school level, the pressure to prepare students for university entrance exams is fierce (long lines are to be found at Shinto shrines to pray for success, each Spring just before the March university entrance exam season), and curricula tend to be structured around test preparation (in Japan each university has its own test, there are no nationally standardized university entrance exams such as the SAT or ACT in the United States). As mentioned above, there are Super Science High Schools, but the small number means that only a tiny fraction of all students are impacted [63].

At the district level, public primary schools do not have a ranking per se. As students move up to middle and high school, however, the ranking in terms of university placement success becomes more stratified. Private schools, being tuition driven, have many resources (including enrichment programs) unavailable to public school students. In Japan, each school district has a ranking of schools, and the highest performing students (based on an entrance examination) enter the top schools. In this sense, clustering of students by ability does occur throughout Japan (at least at the high school level and to a lesser extent at the middle school level). Matsumoto (2007) has argued that a kind of de-facto gifted education system of sorts has evolved in Japan, because of the ability-based sorting by school and supplemental education described above. However, due to the small number of programs, weak development of student creativity in problem-solving skills (e.g., "outside the box" thinking), and cultural bias against "elitism", Matsumoto concludes that progress in developing a national system of gifted education shall remain minimal [64].

Japan is grappling with the aforementioned challenges in its attempt to develop a comprehensive national policy aiming to develop human capital in support of a national innovation system worthy of global competition in the 21 st century. Further, given Japan's long legacy of struggle to integrate Korean and Brazilian Japanese, it is difficult to imagine Japan's national government adopting a 
Singapore style "guppies to whales" program that attracts high ability students from all over Asia, inviting these students to become Japanese citizens.

\section{Conclusions}

This paper has reviewed the history and recent trends in the development of gifted education in East Asian countries. While a number of policies have been established in countries including China, Korea and Singapore, Japan continues to lag behind in the establishment of a national system to support high achieving students, as evidenced by the absence of gifted policies and cultural tendency to equate notions of giftedness with elitism. The United States, given failures in NCLB implementation and budget deficits, has declined in its historical preeminence in gifted education [65].

The differences between the trend in GATE education policy and practice in the Asian countries in this study, compared to the United States (and Japan) are significant. First, in some countries in Asia, supporting the needs of gifted learners is a national level effort. Government policies have signaled that this is an important area for national investment, at all levels of education. In the United States, federal mandates for gifted education are lacking (despite its history of pioneering implementation of gifted education) and individual states have the autonomy to decide whether or not to pursue GATE policies. The majority of states do not [66]. Second, expansion in GATE education in Asian countries including China, Korea and Singapore, has been implemented in tandem with an increase in foreign language acquisition, especially English. These developments have produced an increasingly globally competitive human capital pool. Finally, advances in GATE at all levels in these countries have continued to outpace progress in Japan and the United States. In sum, Japan, in its post Meiji era anti-elitism and the U.S. legacy of similarly anti-elitist Bush era policies, namely NCLB, have proven a drag on human capital development.

As Asian countries continue to rise economically, particularly in terms of leadership in scientific innovation and technology entrepreneurship, future studies are warranted to understanding gifted and enrichment curricula and practice, teacher training as well as long-term studies assessing the impact on student performance and career success of gifted education. Nevertheless, it is clear that significant progress is being made at all levels of the education system, inspiring the best-and-brightest learners in Asia to develop the skills to pursue their dreams. American and Japanese policymakers should ask themselves if they want their countries to be competitors in the "race to the future," and if so, might find inspiration in Confucius:

People being born to know are superior; people learning to know are secondary; people learning to know only when facing a problem are below secondary; people not learning to know even when facing a problem are inferior [67].

\section{Acknowledgments}

Fulbright New Century Scholars Program, 2009-2010 University as Innovation Driver Project; NSF "Advocating for an Inventive and Transformative Recovery in National STEM Education," Award 0947782, E. Anthony Kelly, George Mason University, Principal Investigator 2010; Japan 
Foundation Center for Global Partnership (CGP). Research assistance provided by Liyu Hu and Chao Yang, DePaul University and Keiichiro Koda, Ritsumeikan University.

\section{References and Notes}

1. Zakaria, F. The Rise of the Rest, 2008. The Daily Beast Web site. Available online: http://www.thedailybeast.com/newsweek/2008/05/03/the-rise-of-the-rest.html (accessed on 26 October 2011).

2. Restoring the American Dream: Getting Back to \#1, a Fareed Zakaria GPS Special, online video cast, 2011. CNN.com. Available online: http://www.cnn.com/video/\#/video/podcasts/fareed zakaria/site/2011/05/07/gps.resorting.special.cnn (accessed on 10 November 2011).

3. OECD, PISA 2009 Results: What Students Know and Can Do-Student Performance in Reading, Mathematics and Science; PISA, OECD Publishing: Paris, France, 2010. Available online: http://dx.doi.org/10.1787/9789264091450-en (accessed on 10 November 2011).

4. OECD, PISA 2009 at a Glance; OECD Publishing: Paris, France, 2010. Available online: http://dx.doi.org/10.1787/9789264095298-en (accessed on 10 November 2011).

5. Figure I.3.b, Top performers in reading, math and science: percentage of students reaching the two highest levels of proficiency. What Students Know and Can Do-Student Performance in Reading, Mathematics and Science; PISA 2009 Results: Executive Summary; Organization for Economic Co-operation and Development (OECD): Paris, France, 2009; p. 155.

6. Callahan, C. Keynote Address to Gifted Summit, School District 25, Arlington Heights, IL, USA, 17 April 2011.

7. United States Department of Education. National Excellence: A Case for Developing America's Talent; U.S. Government Printing Office: Washington, DC, USA, 1993.

8. Clark, B. Social ideologies and gifted education in today's schools. Peabody J. Educ. 1997, 72, $81-100$.

9. Clark, B. Optimizing Learning: The Integrative Education Model in the Classroom; Prentice Hall: Columbus, NJ, USA, 2002.

10. Phillipson, N.S.; Shi, J.; Zhang, G.; Tsai, D.-M.; Quek, C.G.; Matsumura, N.; Cho, S. Recent developments in gifted education in East Asia. In International Handbook on Giftedness; Shavinina, L.V., Ed.; Springer Science and Business Media: Amsterdam, The Netherlands, 2009; pp. 1427-1461.

11. The History of Gifted and Talented Education, 2008. National Association of Gifted Children (NAGC) Web site. Available online: http://www.nagc.org/index.aspx?id=607 (accessed on 10 November 2011).

12. Winerip, M.; No Child Left Behind? Ask the Gifted. The New York Times, 5 April 2006. Available online: http://www.nytimes.com/2006/04/05/nyregion/05education.html?_r=1\& pagewanted $=1$ (accessed on 26 October 2011).

13. Preparing the Next Generation of STEM Innovators: Identifying and Developing our Nation's Human Capital; National Science Board: Arlington, VA, USA, 2010. 
14. State of the Nation in Gifted Education: A Lack of Commitment to Talent Development, A Half-Century After Winning the Space Race, Our Nation's Competitiveness is at Risk, National Association of Gifted Children (NAGC); 2010-2011 State of the States Report; National Association of Gifted Children: Washington, DC, USA, 2011. Available online: http://www.nagc.org/ (accessed on 10 November 2011).

15. Research Center for Supernormal Children, Institute of Psychology, Chinese Academy of Science.

16. The first Gifted Pilot Program was established in 1990 in 19 primary schools in grades 3-5; Hong Kong Gifted Education Situation.

17. Lan, L.; Lan, J.J.; Wu, Y.Y. Taiwan Special Education and its enlightenment to mainland's special education. Chin. J. Special Educ. 2008, 12, 20-24, 29.

18. Jacob Javits Gifted and Talented Students Education Act (1988), 2008. National Association for Gifted Children Web site. Available online: http://www.nagc.org/index.aspx?id=572 (accessed on 23 February 2011).

19. Gifted education mandates, funding and provision varies widely by state and school district in the United States. Available online: http://www.davidsongifted.org/db/StatePolicy.aspx (accessed on 23 February 2011). The first comprehensive government study on gifted in US was the following: Marland, S.P., Jr. 1972. Education of the gifted and talented: Report to the Congress of the United States by the U.S. Commissioner of Education and background papers submitted to the U.S. Office of Education, 2 vols. Washington, DC, U.S. Government Printing Office. (Government Documents Y4.L 11/2: G36).

20. March 9, 1978. University of Science and Technology of China create Shao Nian class. People's Daily, 2003. Available online: http://www.people.com.cn/GB/historic/0309/5891.html (accessed on 9 November 2011).

21. Chan, J. Giftedness and China's Confucian heritage. In Conceptions of Giftedness: Sociocultural Perspectives; Phillipson, S.N., McCann, M., Eds.; Lawrence Erlbaum Associates: Mahwah, NJ, USA, 2007; pp. 35-64.

22. Chan J. also reminds us that Asian languages are structured to represent place value in numbering systems, which is advantageous in learning math.

23. How to define the supernormal children. Beijing Daily, June 2009. Available online: http://edu.sina.com.cn/1/2009-06-04/0904172140.shtml (accessed on 26 October 2011).

24. "Top" schools are defined by the Ministry of Education (MOE). There are two classifications: the provincial top schools and the national top schools. The standard of the top school is overall and composite, including the quality of faculty, the academic performance of the students, reputation, and the equipment and settings of the school. For universities, the standard also includes the employment rate of graduates and the number and the quality of the paper and publication by faculty (see top 10 university ranking, below).

25. Gifted Education Situation in Beijing. Beijing Daily, June 2009. 
26. "The Evaluation of Universities in China" ranks universities through a composite score of student performance, teacher quality, facilities and equipment, etc. The Ranking in 2010 is as follows: 1) Tsinghua University, 2) Peking University, 3) Zhejiang University, 4) Shanghai Jiao Tong University, 5) Fudan University, 6) Nanjing University, 7) Wuhan University, 8) Huazhong University of Science and Technology, 9) Zhongshan University, 10) Sichuan University." Wu, S.; Lv, J.; Guo, S. 2010 China universities evaluation. Sci. Sci. Manage. 2010, 4, 5-13.

27. Cha, Z. Research and development of supernormal children in China. Chin. J. Special Educ. 1995, 4, 2-8.

28. The Achievements of Chinese Gifted Education in the Past Thirty Years; National Talented Specialty Committee, Chinese Talents Society: Beijing, China, 2008.

29. Education Commission Report No.4; Education Commission: Hong Kong, China, 1990.

30. An Overview of Gifted Education Development in Hong Kong; Hong Kong Academy for Gifted Education: Hong Kong, China, 2008. Available online: http://hkage.org.hk/en/background.html (accessed on 29 October 2011).

31. GE Provision in Hong Kong; Hong Kong Academy for Gifted Education: Hong Kong, China, 2008. Available online: http://hkage.org.hk/en/background.html (accessed on 29 October 2011).

32. Provision and support for students, 2008. Hong Kong Academy for Gifted Education Web site. Available online: http://hkage.org.hk/en/objectives.html (accessed on 10 November 2011).

33. Wang, Z. The Execution of Gifted Education in Taiwan; Taiwan Education University: Taipei, Taiwan, 2008.

34. Education for Gifted and Talented Students; Ministry of Education, Republic of China (Taiwan): Taipei, Taiwan, 2006. Available online: http://english.moe.gov.tw/ct.asp?xItem=7147\&ctNode= $508 \& m p=3$ (accessed on 11 November 2011).

35. Li, J. Education for Gifted Children in Korea, 2009. Life in Korea Web site. Available online: http://masudjamali.blogspot.com/2009/10/education-for-gifted-children-in-korea.html (accessed on 11 November 2011).

36. Park, K. Gifted Education in Korea; Hongik University: Seoul, Korea, 2009.

37. Gifted Education Programme: Development and Growth; Singapore Ministry of Education: Singapore, 2010. Available online: http://www.moe.gov.sg/education/programmes/giftededucation-programme/development-and-growth/ (accessed on 29 October 2011).

38. Lim Shan-Loong, M. The gifted education programme in Singapore. Ngee Ann Polytechnic: Singapore, 2001 (unpublished paper).

39. Gifted Education in Singapore: The First Ten Years; Singapore Ministry of Education: Singapore, 1994.

40. Frequently Asked Questions: GEP Pupils; Singapore Ministry of Education: Singapore, 2010. Available online: http://www.moe.gov.sg/education/programmes/gifted-education-programme/faq/ gep-pupils/ (accessed on 2 November 2011).

41. Frequently Asked Questions: Exceptionally Gifted Children, 2010. Singapore Ministry of Education Web site. Available online: http://www.moe.gov.sg/education/programmes/gifted-educationprogramme/faq/exceptionally-gifted/ (accessed on 29 October 2011).

42. Singapore Ministry of Education. Education Statistics Digest 2010; Management Information and Research Branch: Singapore, 2010. 
43. Frequently asked Questions: Exceptionally Gifted Children. Number 6. Available online: http://www.moe.gov.sg/education/programmes/gifted-education-programme/faq/exceptionally-gi $\mathrm{fted} /$ (accessed on 28 October 2011). The Ministry of Education (MOE) formally identifies the academically gifted and also the top $1 \%$ (exceptionally gifted) of the national cohort through the Gifted Education Programme (GEP), beginning at primary grade four. Services are also available for the exceptionally gifted.

44. Yeo, P. Singapore's experience-Economic development with science and technology. Presented at Okinawa Institute of Science and Technology, Okinawa, Japan, October 2010.

45. Youth outreach: Wards and scholarships, A Star, 2011. Agency for Science, Technology and Research Web site. Available online: http://www.a-star.edu.sg/AwardsScholarships/Youth Outreach/ResourcesActivities/tabid/162/Default.aspx (accessed on 21 March 2011).

46. Yeo, P. Interview October 2010. The inside track from academia and industry: (And they call it) guppy love. Nature 2007, 446, 948. Available online: http://www.nature.com/naturejobs/2007/ 070419/full/nj7138-948a.html (accessed on November 8, 2011).

47. Frequently Asked Questions, Singapore Agency for Science, Technology and Research, A*STAR Scholarship Schemes Web Site. Available online: http://www.ifaq.gov.sg/astar/apps/fcd_faqmain.aspx?qst=2fN7e274Rap\%2bbUzLdEL\%2fmCxs7 iwcgv8gv2atNDOvsLBoEPjeVfBwYQARP2mzrBOgONityUs1EGGD6M\%2bsc3\%2by\%2fgVv BGnZM3ciHu\%2bicFRn2nzXqw5jatJdc\%2f15LHbWWETJ4ZoxxyWkuCVAwgEBhvLWx\%2b xMzzD7h8bGjgp4mw0268\%2bIgCpCcjzvmbcZBTudIbczYP0om3\%2f6HG\%2fxdy5EqEZAamp 5i9BllF\%2fAynjqFpn6TAELNMTY\%2fn\%2beLg\%3d\%3d (accessed on 8 November 2011); Permanent residents and foreigners who are awarded the scholarship will be required to take up Singapore citizenship.

48. Interview with Gifted Student M; Nanyang Technical University: Singapore, 2010.

49. Yokohama Science Frontier High School, 2010. Yokohama City Board of Education Web site. Available online: http://www.city.yokohama.lg.jp/kyoiku/sidou2/koukou/sfh/ (accessed on 9 November 2011).

50. Fujino, M. Increasing the Provision of Opportunities for the Motivation of Expanding Recipients of 'Talent Education'. Tokyo Daily, 27 April 2010. Available online: http://mainichi.jp/select/ science/rikei/news/20100427ddm016040057000c.html (accessed on 25 February 2011).

51. This may be related to the notion within Confucianism equating ability with effort (and not natural talent). Chan, J. Giftedness and China's Confucian heritage. In Conceptions of Giftedness: Sociocultural Perspectives; Phillipson, S.N., McCann, M., Eds.; Lawrence Erlbaum Associates: Mahwah, NJ, USA, 2007; Cited in Phillipson et al. 2009.

52. Stevenson, H.W.; Lee, S.Y.; Chen, C.S.; Kato, K.; Londo, W. Education of gifted and talented students in China, Taiwan and Japan. In National Excellence: A Case for Developing America's Talent; O'Connell, R.P., Ed.; Office of Education Research and Improvement, US Department of Education: Washington, DC, USA, 1994.

53. Kyoto municipal senior high school web site. Available online: http://www.edu.city.kyoto.jp/ hp/horikawa/ (accessed on 23 February 2011). 
54. Matsumura, N. Giftedness in the culture of Japan. In Conceptions of Giftedness: Sociocultural Perspectives; Phillipson, S.N., McCann, M., Eds.; Lawrence Erlbaum Associates: Mahwah, NJ, USA, 2007; Cited in Phillipson et al. 2009.

55. Report from the Review of Supports for Science Education Task Force; Talent Education Committee: Tokyo, Japan, 2010; p. 20. Available online: http://rikashien.jst.go.jp/highschool/ 2009shiryo.html (accessed on 23 February 2011).

56. Report from the Review of Supports for Science Education Task Force; Talent Education Committee: Tokyo, Japan, 2010; p. 66; Figure 25.

57. See, for example, Ishikawa Hiroyuki. A study on the vision and the structure of the educational system for the gifted and talented in South Korea, National Institute of Informatics Scholars and Academic Information Navigator 2005, 51, 114-127.

58. Kitamura, K.; Kuramoto, N. Education for the gifted in science and mathematics and freshman admissions in Korea. Educ. Inform. Res. 2005, 3, 135-143.

59. Nozoe, K. The Present state of gifted education in China compared to America. J. Asian Cultures 2007, 9, 63-91.

60. Zhao, J. A Study on talented education of high school in China: Concentrating on the national scientific pilot class. Tobiume: Bulletin of Education Course Graduate School Kyushu University 2003, 3, 145-160.

61. Kumon Home Page. Available online: http://www.kumon.ne.jp/ (accessed on 26 February 2011).

62. Benesse Home Page. Available online: http://www.benesse.co.jp/ (accessed on 26 February 2011).

63. The Situation Regarding Bias in Classroom Lectures Towards Written University Exams that Disregards Experiments and Exploration as Preparation for University Entrance Examinations in High School Science Education; Report from the Review of Supports for Science Education Task Force; Talent Education Committee: Tokyo, Japan, 2010; p. 24.

64. Matsumoto, N. Giftedness in the culture of Japan. In Conception of Giftedness: Socio-Cultural Perspectives; Phillipson, S.N., McCann, M., Eds; Lawrence Erlbaum Association: Mahwah, NJ, USA, 2007.

65. As the parent of "gifted" learners, who have been educated in both the United States and Japan, I have seen firsthand the impact NCLB in the U.S. has had on the classroom. More time is spent preparing average ability learners for the quarterly "test weeks", not to mention the lost instruction time in the weeks that tests are taken. Meanwhile gifted learners are left to their own devices, since they already perform well on these exams. Remaining in Japan, on the other hand, would mean an extended day of evening "juku" lessons, to supplement rigid classroom curricula and also prepare for high school/university entrance exams.

66. Gifted by State, 2008. National Association of Gifted Children (NAGC) Web Site. Available online: http://www.nagc.org/index.aspx?id=37 (accessed on 8 November 2011).

67. Chan J. Sheng er zhi zhi zhe, shang ye, xue er zhi zhi zhe, ci ye; kun er xue zhi you qi ci ye; kun er bu xue, min si wei xia yi. In Conception of Giftedness: Socio-Cultural Perspectives; Phillipson, S.N., McCann, M., Eds; Lawrence Erlbaum Association: Mahwah, NJ, USA, 2007. 
Appendix: Education by Student Population, Institution

Table A1. Number of students.

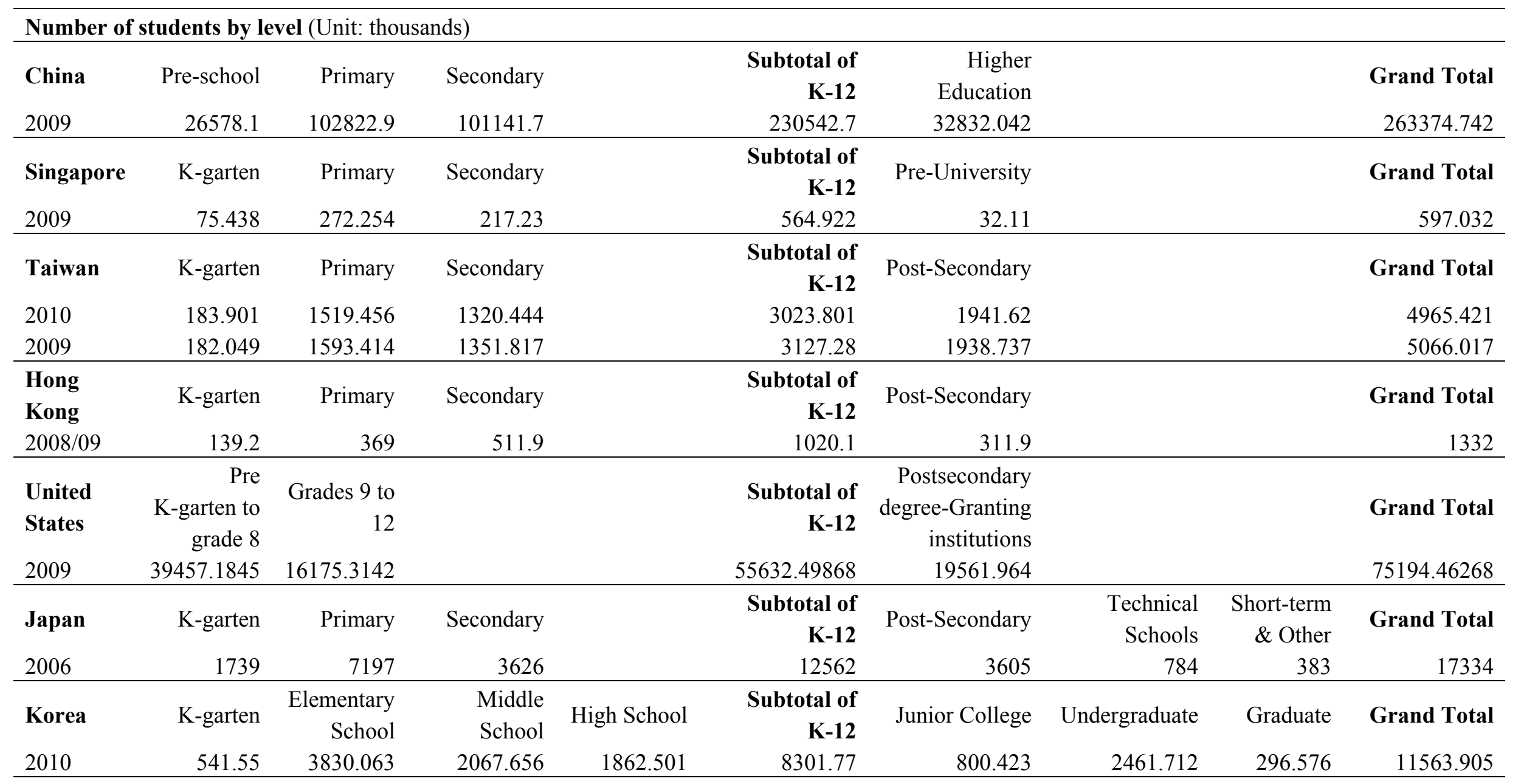

Note: Total population in above countries: China, 1.337 billion; Singapore, 4.741 million; Taiwan, 23.518 million; Hong Kong, 7.123 million;

United States, 313.232 million; Japan, 126.476 million; South Korea, 48.755 million (July 2011 est.) (Data from Central Intelligence Agency, World Fact

Book. Available online: https://www.cia.gov/library/publications/the-world-factbook/fields/2119.html\#xx (accessed on 6 January 2012). 
Table A2. Number of institutions.

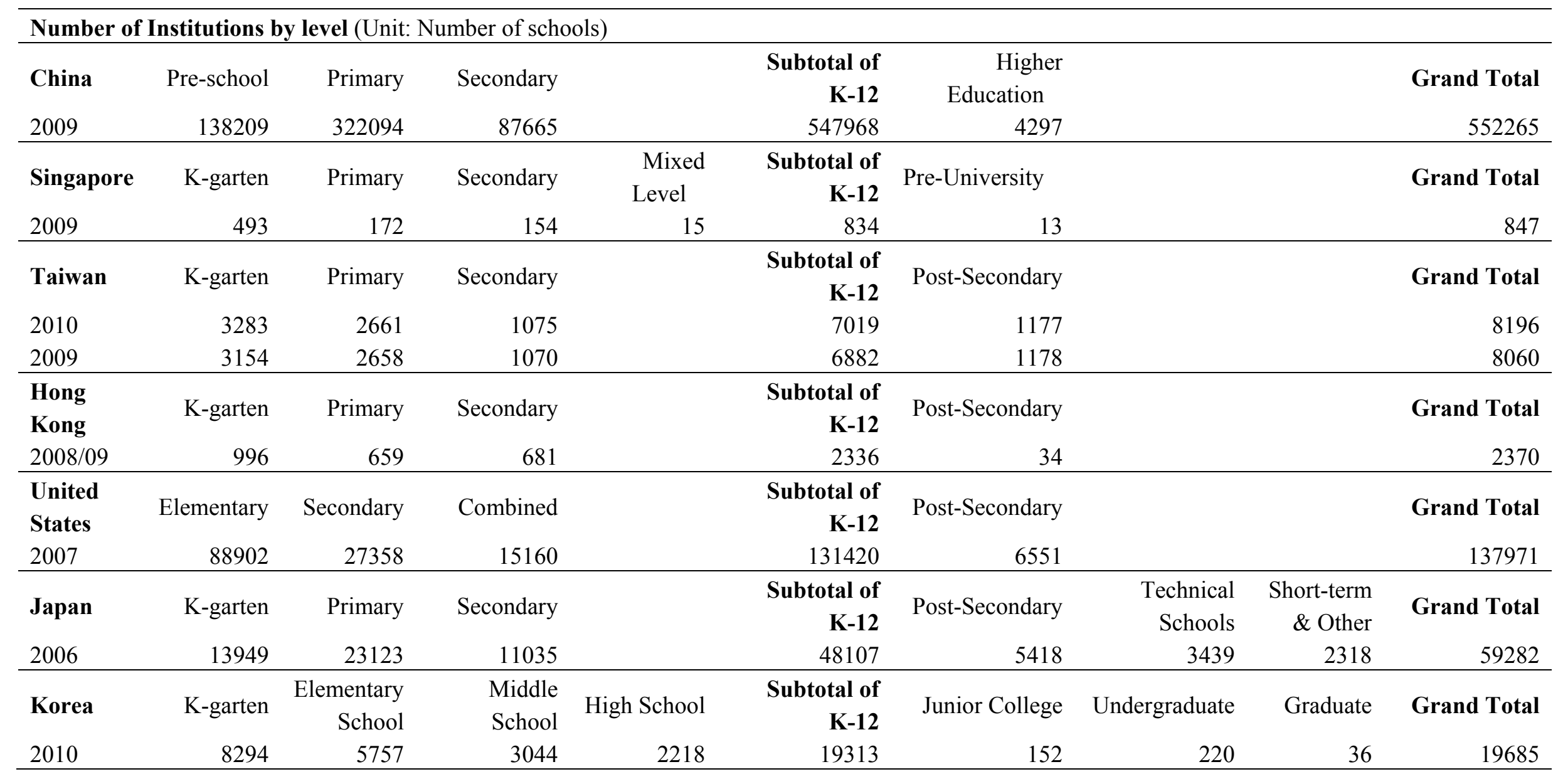


Table A2. Cont.

Note:

The category Mixed Level, which caters to schools with multiple levels, encompasses Primary \& Secondary Schools(P1-S4/5), Secondary \& Junior College Schools(S1-JC2); and Upper Secondary and Junior College (S3-JC2).

Pre-University Course include enrollment in Junior Colleges, Centralized Institutes and Pre-U Centers.

Higher Education includes Institutions providing postgraduate programs, Regular HEIs, Adult HEIs and Non-state/private HEIs.

1. Singapore: From the Ministry of Education in Singapore, URL: http://www.moe.gov.sg/education/education-statistics-digest/, accessed 20 February 2011;

2. Taiwan: From the Taiwan Statistic Bureau website, URL: http://ebas1.ebas.gov.tw/pxweb/Dialog/statfile1L.asp, accessed 20 February 2011;

3. Hong Kong: From the Education Bureau website, URL: http://www.edb.gov.hk/index.aspx?nodeID=92\&langno=1, accessed 20 February 2011;

4. China: From the Ministry of Education website, URL: http://www.moe.edu.cn/publicfiles/business/htmlfiles/moe/s4959/201012/113477.html\#, accessed 20 February 2011;

5. Korea: From the Ministry of Education website, URL: http://english.mest.go.kr/web/1721/site/contents/en/en_0219.jsp, accessed 20 February 2011;

6. United States: U.S. Department of Education, National Center for Educational Statistics, Enrollment educational institutions, by level and control of institution: Selected years, fall 1980 through fall 2009, http://nces.ed.gov/programs/digest/d09/tables/dt09_005.asp Number of educational institutions, by level and control of institution: Selected years, 1980-1981 through 2007-2008. http://nces.ed.gov/programs/digest/d09/tables/dt09_005.asp, accessed 25 February 2011;

7. Japan: From “Japan Education at a glance 2006”, http://www.mext.go.jp/english/statist/index.htm, accessed 20 February 2011.

(C) 2012 by the authors; licensee MDPI, Basel, Switzerland. This article is an open-access article distributed under the terms and conditions of the Creative Commons Attribution license (http://creativecommons.org/licenses/by/3.0/). 